\title{
PERGEPTIONS REGARDING THE PROFILE OF AN IDEAL PROJECT MANAGER
}

\author{
Mihaela Lutaș ${ }^{1}$, Răzvan Nistor ${ }^{2}$, Marius $\operatorname{Radu}^{3}$ and Ioana Beleiu ${ }^{4 *}$ \\ ${ }^{1223) 4)}$ Babeș-Bolyai University, Cluj-Napoca, Romania
}

\section{Please cite this article as:}

Lutas, M., Nistor, R., Radu, M. and Beleiu, I., 2020.

Perceptions Regarding the Profile of an Ideal Project

Manager. Amfiteatru Economic, 22(54), pp. 608-622.
Article History

Received: 15 November 2019

Revised: 20 January 2020

Accepted: 3 February 2020

DOI: $10.24818 / \mathrm{EA} / 2020 / 54 / 608$

\begin{abstract}
Nowadays, projects are a common mean of organizing activities in all fields, aspects concerning project management representing a current research topic. While people are considered the most valuable asset of an organisation, project managers can be seen as key players for projects' success, a topic of great interest due to the high number of failing projects. The research aims to identify the profile of an ideal project manager, by presenting an overview of studies regarding the profile of a good project manager and, on the other hand, by analysing the perceptions of organisations' managers and HR specialists regarding the profile of the project manager. The research method is based on the conjoint analysis, for a more realistic approach. Thus, a controlled set of different project manager candidates' profiles is presented in pairs to respondents, who are asked to express their preference. As a result, the article proposes an instrument applicable within any organisation, to identify the profile of the project manager best suited for the role. Firstly, the empirical research provides evidence that persons involved in project managers' selection perceive the value of education, certification, experience or soft skills differently, based on their professional role. Secondly, it shows that project management certifications are relevant for project managers' selection and are much appreciated around the world. Although each project requires specific skills and competencies for the project manager, the research ascertains a preferred profile based on the perception of over one hundred respondents, involved in the selection process of project managers.
\end{abstract}

Keywords: project, project manager, project management certificates, profile, selection.

JEL Classification: J24, M12, M51.

\footnotetext{
* Corresponding author, Ioana Beleiu - ioana.beleiu@econ.ubbcluj.ro
} 


\section{Introduction}

Projects are more than a set of activities conducted to achieve certain objectives, but temporary organizations, according to the definition given in the PRINCE2 international standard: 'a temporary organization that is needed to produce a unique and predefined outcome or result at a given time using predetermined resources' (Office of Government Commerce, 2009, p.4). The uncertainty that characterises projects determines an elevated level of risk in this field, that might lead to failure but is necessary to reach competitive advantage. The increased frequency of using projects represents an adjustment of economic activities to the current environment, characterized by complexity and dynamism, while project management is one of the challenges that organizations face. Projects are valued not only for financial basis but also for intangible benefits hardly measurable in technologies, innovation, knowledge management, and human resource management.

The project manager role is extremely complex and unique since it is based on temporary assignments and lack of formal positions (Bredin \& Söderlund, 2013), being a challenge to employees in organisations. It can be described through a list of tasks and a wide range of responsibilities. Several studies that focus on the profile of the ideal project manager, on successful project managers and on project manager's career development (Muller \& Turner, 2010; Hölzle, 2010; Fisher, 2011; Bredin \& Söderlund, 2013; Ramazani \& Jergeas, 2014; Bredillet et al., 2014; Joseph \& Marnewick, 2018), are discussed below in the theoretical section of the paper. The research presented in this article complements previous research on the topic of project manager's role, aiming to identify the competences and abilities that are perceived to be the most important for an ideal project manager, through an analysis based on the choice of associations targeting the preferences for the different competencies and abilities of the potential project managers. The main question answered through the current research is: What are the competencies required for an ideal project manager, according to HR specialists and organisations' managers? The analysis gives the opportunity to understand better how changes in project managers' profiles influence the candidates' professional value, as it is perceived by key project stakeholders involved in project initiation and project managers' selection. The methodology proposed in the article based on the choice-based conjoint analysis can be applied in practice, facilitating the identification of a project managers' preferred profile, thus contributing to improve the chances of choosing the right person for this role.

The research topic is relevant in the current economic context, where, according to PMI, more than one-third of projects fail to reach their objectives (Project Management Institute, 2013a) and billions of dollars are spent annually on projects with high failure rates (Serrador \& Pinto, 2015). In an environment that demands employees to improve continuously their skills and competences, several studies link project managers and their competencies to project success. Zang et al. (2013) argue that competent project managers are critical to project success, selecting the right person for the job requiring special attention. Another aspect that can influence projects' success is a clear definition of roles and responsibilities

This article includes a review of the literature on the selection and profile of the project manager, the presentation of the proposed conceptual model used for identifying the ideal profile of a project manager, the research methodology and a section that includes data analysis and interpretation of results. The article ends with a set of conclusions that summarises the findings, presents the limits and future directions of the research. 
The research enhances the current literature in the field by achieving its aim of creating a complex profile of the ideal project manager, based on different perceptions.

\section{A review of the relevant literature on project managers' selection and profile}

It is widely accepted that one of the most valuable resources available for an organization to be competitive is the human resource (Segalla et al., 2001). According to the Project Management Institute (Project Management Institute, 2013b), between 2010 and 2020, 15.7 million new project management roles will be created globally. Considering the importance of the project manager, as a key party that relates the permanent structure of an organization with the temporary project team and has the main contribution to achieving the desired outcomes, there can be identified a significant interest in project management research concerning this key role.

The project manager is a member of the project team, which reports to the project owner team, is accountable to stakeholders and has as main objectives: representing the interests of the project, making sure that project goals are achieved, directing the project team, representing the project to relevant environments, overseeing the preparation of project documentation (Gareis, 2005). The leadership of the project team and the responsibility of transferring project's results into the organization (Hölzle, 2010) should also be mentioned when describing the role of project manager. Being a project manager can be perceived as a profession (Bredin \& Söderlund, 2013), in many cases a person having this role for several times, in different projects. Therefore, recruiting and selecting the right project manager for a certain project is a challenge for every organization (Ahsan et al., 2013). According to Taylor (2006), recruitment and selection are probably the most frequently approached subjects by the human resource management courses and books and the first step in building any organization, permanent or temporary.

The recruitment process has the role of attracting the right persons from the labour market, dealing with increased competition for human resource (Ma \& Allen, 2009). Ahsan et al. (2013) conducted a study on the recruitment process to analyse project manager's competencies mentioned in job advertisements as signals that organizations communicate to potential candidates. Without focusing too much on recruitment aspects, it is necessary to mention that both internal and external recruitment are possibilities to be taken into consideration when searching for a project manager, depending on variables like the level of innovation required by the project environment, the available human resources within the organization, the time and financial resources available for conducting the recruitment process. By focusing on the selection process for project managers, the current research continues the study mentioned above. The focus is on external project managers, hired in the project initiation phase.

The primary goal of a selection process is choosing from several candidates the most suitable one, the person that is closer to the required standards of performance and has the highest chance to achieve project's, organisation's and his objectives as well. Existing studies emphasize the presence of several factors that influence the process of selecting a candidate for a job. For example, Segalla et al. (2001) conducted a research based on the opinions of almost 300 managers to identify top characteristics that justify hiring a person: training in foreign languages, test scores, abilities to handle small/ medium size enterprises, references, international work experience, academic background, technical skills. The topic 
remains of interest in the current economic environment (Salas \& Velasco, 2012; Kar \& Mitra, 2015), reason why we approached this issue focusing on factors that influence the hiring of project managers.

Often the project manager is selected before setting the requirements and organizational form of the project. The project manager recruitment and selection process in the initiation phase have critical importance for the relation between the project manager and the stakeholders, and for the value perceived by the project sponsor. Since success usually means different things to different people (Shenhar et al., 2001), the project manager can influence success through an appropriate relationship with the key stakeholders. When dealing with project success, reaching project's objectives within a specified timeframe and with a predetermined budget is usually not enough. Project success is a complex and multidimensional concept (Mir \& Pinnington, 2014), influenced by a series of factors (Pollack \& Algeo, 2016). The identified factors affecting projects' success are the competencies of the project manager, alongside with cooperation and communication, timing, identifying/ agreeing objectives, stakeholder satisfaction, acceptance and use of final products, cost/ budget aspects, strategic benefits of the project and top management support. Moreover, the project manager can influence success factors to increase chances of obtaining the desired outcomes (Westerveld, 2003). The project manager must satisfy the requirements of the customer and answer to senior management by generating a fair return on investment (Forsberg et al., 2005). Thus, selecting a competent project manager with adequate skills is essential, since this decision is critical to project success.

Professional associations have a significant contribution to the knowledge development in the field of project management. In the IPMA Competence Baseline (ICB) international standard, the International Project Management Association (IPMA) approaches the 'eye of competence' which describes a combination of three competence elements necessary for managing a project: technical, behavioural, and contextual (IPMA, 2015). Another international project management professional organisation, Project Management Institute (PMI) developed the Project Manager Competency Development (PMCD) Framework that includes three principal components: knowledge, performance, and personal (Project Management Institute, 2007). Academicians on the other hand, also have an important contribution to creating the profile of good project manager. Muller and Turner (2010) conducted an extended study to examine leadership competency profiles of successful project managers in distinct types of projects by analysing intellectual, managerial and emotional competencies. One of the key findings stated is that competencies of a successful project manager differ depending on project types (Muller \& Turner, 2010). Hölzle (2010) presents in his study the following competencies as required for a project manager to face the challenges of a unique and temporary organization, varying according to the type and scope of the project: project-specific expertise, problem-solving competence, leadership, social, entrepreneurial and project management competence. Another study, conducted by Ramazani and Jergeas (2015) focuses on the requirements for competent project managers, divided into three categories: individual characteristics - such as personality, ability, and motivation; education - referring to academic education; development - relating to experience and professional development. After selecting the right persons for the project manager role, certain deviations from the needed profile can be decreased through education and a continuous training process (Ramazani \& Jergeas, 2015). 
A successful project manager is a motivator, a coordinator, and a leader that must be able to guide a diverse team toward integrated results. Successful project managers possess the following essential skills: people skills; management skills; business expertise; technical knowledge (Chen, 1997). Sommervile et al. (2010) stated that the roles of a project manager change; and their nature modifies according to the maturity of the project manager. When different industries or business approaches are considered, it is needed to zoom into a more refined set of skills. For example, for an outsourcing IT project, the project manager may have distinct roles: leader, resource allocator, spokesman, entrepreneur, liaison or monitor (Karlsen \& Gottschalk, 2006). People, business, management and technical skills may be detailed and particularized to IT outsourcing business needs or another type of business field. According to Bredillet et al. (2015), 'a competent project manager is the one who possesses some attributes to fulfil her or his role; and will demonstrate a certain level of performance.' There are no universally agreed definitions or theories referring to the necessary competencies within the project management field (Zhang et al., 2013), thus creating the portrait of the ideal project manager is a challenging task.

\section{The proposed conceptual model for identifying the ideal profile of a project manager}

Although the profile of a successful project manager is addressed in the literature, there is no consensus on the skills and competencies required. Based on the literature, we determined four main categories of factors that describe the profile of a good project manager. This approach aims to propose a complex profile, which integrates on the one hand the approaches of researchers and international organizations in the field, and on the other hand to highlight the importance of certifications in project management.

- Experience (technical vs. managerial)

Work experience is one of the factors influencing the competencies of a manager. Experienced project managers are used to technical aspects of project management such as critical path analysis, work breakdown structures, resource allocation, and risk management, but also with technical aspects of the business (e.g. for IT industry a project manager might have experience in writing software code). In the present research, technical experience is associated with non-managerial business development activities, while management experience concerns only project management activities related to decision making, resources management, leadership, control and coordination. Further, in our research, we analyse whether management experience is more valuable than technical experience when it comes to hiring a project manager. Jennifer Mateyaschuk mentioned in InformationWeek that project managers with both technical and business skills can earn as much as $25 \%$ more than project managers who have only technical skills (Sommerville et al., 2010).

\section{- Certification in project management}

There is an accepted assumption within the business world, of a positive relationship between applying project management standards and effective workplace performance 
(Crawford, 2005). Project management professional organisations provide guidelines that support projects' implementation known as standards or bodies of knowledge and offer certification possibilities. Morris et al. (2006) conducted a study that explores the role of bodies of knowledge in defining the project manager profession, concluding that practitioners have an interest in bodies of knowledge since they influence industries' views on competence, best practice, training, and development. PMI, the largest professional association in this field, has over 500,000 certification holders in the year of 2015; from 180 different countries and every industry (Project Management Institute, 2015). The certifications offered by PMI are: Certified Associate in Project Management (CAPM) and Project Management Professional Certificate (PMP). Other worldwide recognized organizations offering certification possibilities are: Association for Project Management (APM), International Project Management Association (IPMA), Axelos - offering the PRINCE2 certification, most popular in the UK; and CompTIA - most popular in the IT field. These international organizations provide different certification opportunities in project management, depending on the needs, knowledge and experience in the field. Thus, the project management certification can be classified as knowledge-based and competency-based. Opposite to the knowledge-based certificates that require theoretical knowledge, competency-based certificates also require practical experience in the field. Project management certification is usually seen as a step towards the professionalisation of the project management field. Certifications aim to provide individuals with the appropriate knowledge and skills required to successfully manage projects (Joseph \& Marnewick, 2018). Although certifications do not guarantee project manager's competencies, they can provide a competitive advantage in a selection process.

\section{- Education in the project field}

Education is also a relevant factor that outlines the profile of a good project manager. Project managers are expected to bring a high degree of technical knowledge to solving problems (Chen, 1997). Bauer et al. (2014) support the idea that successfully managing a project implies a certain level of technical capability, which can be obtained through formal education in the field of the project.

- Soft skills

On the other hand, some authors support the importance of soft skills for successfully managing projects. The necessary specialized knowledge and experience might not always be enough. Managers also need to be versatile and capable of dealing with a variety of circumstances (Mediouni et al., 2018). In his research on effective project managers, Fisher (2011) emphasises the importance of people skills and behaviours, such as: understanding behavioural characteristics, leading others, influencing others, conflict management and cultural awareness. Zhang et al. (2013) and Obradovic et al. (2013) also mention emotional competencies as necessary for a successful project manager, since they influence important behaviours, such as leadership, teamwork, workgroup effectiveness, and managing conflicts. 


\section{Research methodology}

The empirical research aims to assess the importance of project manager's skills and competencies as they are perceived by persons involved in project managers' selection process. The study complements the existing literature on the topic by providing an instrument that can be applied to any organisation, to identify the profile of the project manager best suited for projects. Data analysis and results interpretation are based on quantitative research and can be divided into three main phases:

- Phase 1 - Analysing respondents' preferences for the four categories of factors influencing the selection decision.

- Phase 2 - Analysing the responses based on the occupation of the respondent (organisations' managers or HR specialists) and based on the geographical location. In this phase of the research it is also analysed whether project management professional certificates are valued differently in various locations around the world.

- Phase 3 - Identifying the preferred profile of a project manager, based on the received responses.

The questionnaire was used as an instrument for data collection. Instead of directly asking the respondents what the most valuable skills and competencies for a manager are, conjoint analysis was used to provide a more realistic approach. In Choice-Based Conjoint (CBC) a controlled set of different project manager candidates' profiles is presented in pairs to respondents. A project manager profile is defined as a particular selection of skills and competencies. The respondent is expected to mark the preference for the project manager candidate profile considered to be more valuable to the project. Further, the characteristics of project managers are assessed based on respondent's preferences between these profiles. The factors considered in the research are presented in (table no.1) and refer to experience, certifications, education and soft skills. All the mentioned factors are important when selecting a project manager, but some of them might influence the choice more than others.

Table no. 1: Factors used for fractional factorial design

\begin{tabular}{|c|l|}
\hline Factors & \multicolumn{1}{|c|}{ Levels } \\
\hline \multirow{2}{*}{ Experience } & $(-)$ with technical experience \\
\cline { 2 - 2 } & (+) with management experience \\
\hline \multirow{2}{*}{ Certifications } & (-) NA \\
\cline { 2 - 2 } & (+) project management certified (e.g. Prince2, PMP, Comptia Project+) \\
\hline \multirow{2}{*}{ Education } & $(-)$ NA \\
\cline { 2 - 2 } & (+) higher education in the project field \\
\hline \multirow{2}{*}{ Soft Skills } & $(-)$ team player, adaptable, with strong communication skills \\
\cline { 2 - 2 } & $(+)$ with teaching, training and mentoring skills \\
\hline
\end{tabular}

From the four categories of factors presented above were constructed 16 different project manager candidates' profiles in a full factorial design. Out of this full design, it was extracted a fractional factorial design (orthogonal array) containing eight such profiles. Using these profiles, pairs were created and presented to respondents using a web-based 
questionnaire. For each pair, respondents were asked to select the preferred manager profile as shown in (figure no. 1).

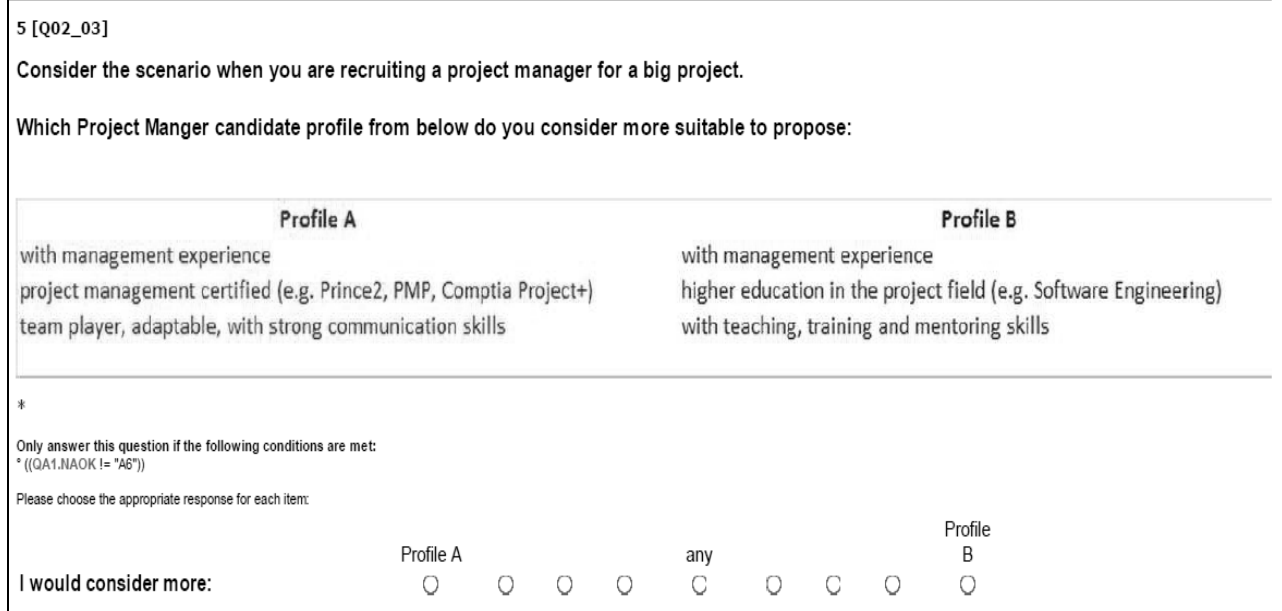

Figure no. 1: Pair of profiles

The questionnaire was constructed and applied using LimeSurvey, an open source webbased survey solution. The target population includes persons who were involved in project managers' selection; and is divided into two main groups: HR specialists and organisations' managers (entrepreneurs and individuals within the management structure of the organisation with decision power in the selection process). The questionnaire was distributed via social networks (LinkedIn and Twitter) to relevant environments. The sampling method was based on self-selection.

A number of 280 persons have answered the questionnaire, and 119 (42.5\%) have qualified as respondents included in the targeted population. Most of the respondents are males $(50.42 \%)$, from Europe (46.22\%), holding management positions $(63.02 \%)$. A percentage of $35.29 \%$ of the respondents are human resource specialists involved in the selection process of project managers for IT projects, engineering and construction projects, research and development projects, human resource development projects or organisational change projects. Demographic data regarding the respondents and a detailed picture of the sample are presented in (table no. 2).

Table no. 2: Demographic data

\begin{tabular}{|c|c|c|c|c|c|c|c|c|}
\hline Occupation & No. & $\%$ & Continent & No. & $\%$ & Gender & No. & $\%$ \\
\hline Manager & 75 & 63.02 & Europe & 55 & 46.22 & Males & 60 & 50.42 \\
\hline HR specialist & 42 & 35.29 & Other than Europe & 34 & 28.57 & Females & 36 & 30.25 \\
\hline Unspecified & 2 & 1.69 & Unspecified & 30 & 25.21 & Unspecified & 23 & 19.33 \\
\hline Total & 119 & 100 & Total & 119 & 100 & Total & 119 & 100 \\
\hline
\end{tabular}


Each respondent stated the preference for each of the eight project manager profiles presented in pair with another alternative profile selected randomly out of the seven remained in the orthogonal array. The analysed dataset contained 1904 records from the controlled experimental design. The data was processed by using $\mathrm{R}$ statistical software environment.

\section{Data analysis and results interpretation}

In the first phase of the research, the valid data were analysed using general linear models (GLM1). As a first step, the influence of the studied factors (work experience, certification, education and soft skills) on respondents' preferences are assessed using two different regression models:

- Linear regression model presented in (table no. 3). In this case, the preference was coded from 1 to 9 , where 9 is the most preferred profile and 1 is the least preferred profile.

- Logistic regression model presented in (table no. 4). In this case, the preference was coded from 1 or 0 , where 1 is the value of the most preferred profile and 0 represents the least preferred profile.

Table no. 3: Linear regression results on full model

\begin{tabular}{|c|c|c|c|c|}
\hline Coefficients & Estimate & Std. Error & t value & $\operatorname{Pr}(>|\mathbf{t}|)$ \\
\hline (Intercept) & 2.90 & 0.23 & 12.54 & $<2 \mathrm{e}-16 * * *$ \\
\hline $\begin{array}{l}\text { Experience: with management } \\
\text { experience }\end{array}$ & 0.23 & 0.12 & 1.84 & 0.0663 \\
\hline $\begin{array}{l}\text { Certification: project } \\
\text { management certified (e.g. } \\
\text { Prince2, PMP) }\end{array}$ & 1.69 & 0.12 & 13.68 & $<2 \mathrm{e}-16 * * *$ \\
\hline $\begin{array}{l}\text { Education: higher education in } \\
\text { the project field }\end{array}$ & 1.95 & 0.12 & 15.82 & $<2 \mathrm{e}-16 * * *$ \\
\hline $\begin{array}{l}\text { Soft Skills: team player, } \\
\text { adaptable, with strong } \\
\text { communication skills }\end{array}$ & 0.30 & 0.12 & 2.42 & $0.0158 *$ \\
\hline Set & 0.01 & 0.12 & 0.10 & 0.9187 \\
\hline
\end{tabular}

The main result of this analysis is the fact that the order of factors' relevance regarding the preference is the same in both regressions. Thus, based on the results presented in (table no. 3 ), education is the most influential factor, followed by certification, soft skills, and experience.

In both regression models, it was used a dummy variable called 'Set' which identifies the position (left or right) of the profile presented in each pair. This was constructed to assess if the profile presentation has an influence on respondent's preference. It was observed that the position of the profiles (on the left or right), does not influence the preference. 'Set' coefficient and $\mathrm{p}$ values are presented in (table no. 3). Further on, we excluded this irrelevant factor from logistic regression results presented in (table no. 4). 
Table no. 4: Logistic regression results on full model

\begin{tabular}{|c|c|c|c|c|c|c|c|}
\hline \multirow[t]{2}{*}{ Coefficients } & \multirow[t]{2}{*}{ Estimate } & \multirow[t]{2}{*}{ Std. Error } & \multirow[t]{2}{*}{$\mathrm{z}$ value } & \multirow[t]{2}{*}{$\operatorname{Pr}(>|z|)$} & \multirow[t]{2}{*}{ OR } & \multicolumn{2}{|c|}{$\begin{array}{l}95 \% \text { CI for } \\
\text { Odds Ratio }\end{array}$} \\
\hline & & & & & & 0.025 & 0.975 \\
\hline (Intercept) & -1.67 & 0.12 & -13.38 & $<2 \mathrm{e}-16 * * *$ & 0.19 & 0.15 & 0.24 \\
\hline Experience & 0.17 & 0.10 & 1.71 & 0.0866 & 1.19 & 0.98 & 1.45 \\
\hline Certification & 1.23 & 0.10 & 12.07 & $<2 \mathrm{e}-16 * * *$ & 3.43 & 2.81 & 4.20 \\
\hline Education & 1.31 & 0.10 & 12.82 & $<2 \mathrm{e}-16 * * *$ & 3.71 & 3.04 & 4.54 \\
\hline Soft Skills & 0.26 & 0.10 & 2.57 & $0.0101 *$ & 1.30 & 1.06 & 1.58 \\
\hline \multicolumn{8}{|c|}{ 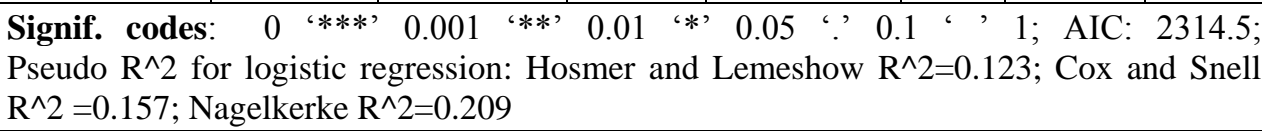 } \\
\hline
\end{tabular}

The logistic regression analysis shows the significant $(\mathrm{p}<0.05)$ influencers for respondents' preference are: Education $(\mathrm{B}=1.31, \mathrm{SE}=0.1)$, Certification $(\mathrm{B}=1.23, \mathrm{SE}=0.1)$, Soft Skills $(\mathrm{B}=0.26, \mathrm{SE}=0.1)$ and Experience $(\mathrm{B}=0.17, \mathrm{SE}=0.1$, when $\mathrm{p}<0.1)$. When it comes to the factor referring to soft skills, teaching, training and mentoring skills (preference mean is 4.86) are less appreciated than a team player and communication skills (preference mean is $5.15, \mathrm{p}=0.03)$.

The main objective of the second phase of the research is testing the two-hypothesis formulated in the previous section. The odds ratios of the four factors from full logistic regression model for all respondents is shown in (figure no. 2). The odds ratio greater than 1 indicates that as the predictor increases, the occurring odds increase for the preference concerning the profile presented.

The main outcomes of the analysis appear when we focus on the regression analysis realized for two different respondent groups: organisations' managers vs. HR specialists. Respondents with management orientation appreciate the project management certifications more than higher education in the project field (IT, engineering and construction, etc.) while HR specialists value the higher education in the project field more than management certificates. Organisations' managers appreciate differently than HR specialists what is important when hiring a project manager. As expected, the results indicate that a person's previous work experience influences the perception regarding the profile of a good project manager. Moreover, soft skills and management experience are not so relevant when respondents must select a project manager candidate. In comparison with managementoriented respondents, HR specialists appreciate more education in the project field and management certification and less management experience and soft skills when it comes to selecting a preferred candidate profile.

By analysing the answers of respondents from Europe and respondents from other continents, the primary outcome is that stakeholders involved in project managers' selection from Europe appreciate more the candidates with project management certificates such as PMP, Prince2 or Comptia Project+. Thus, it can be said that project management professional certificates are appreciated differently in various locations around the world. It is important to mention a certain level of limitation when discussing this result, due to the decreased number of answers from other continents than Europe. There were 34 respondents from other continents, as follows Asia: 8 respondents (India: 6, Vietnam: 1, 
Singapore: 1); North America: 21 respondents (USA: 20, Canada: 1); other: 5 respondents. This outcome can be considered more an insight than a result. For more accurate results the subject should be further researched in depth with extensive studies that respect sampling constraints regarding continents.

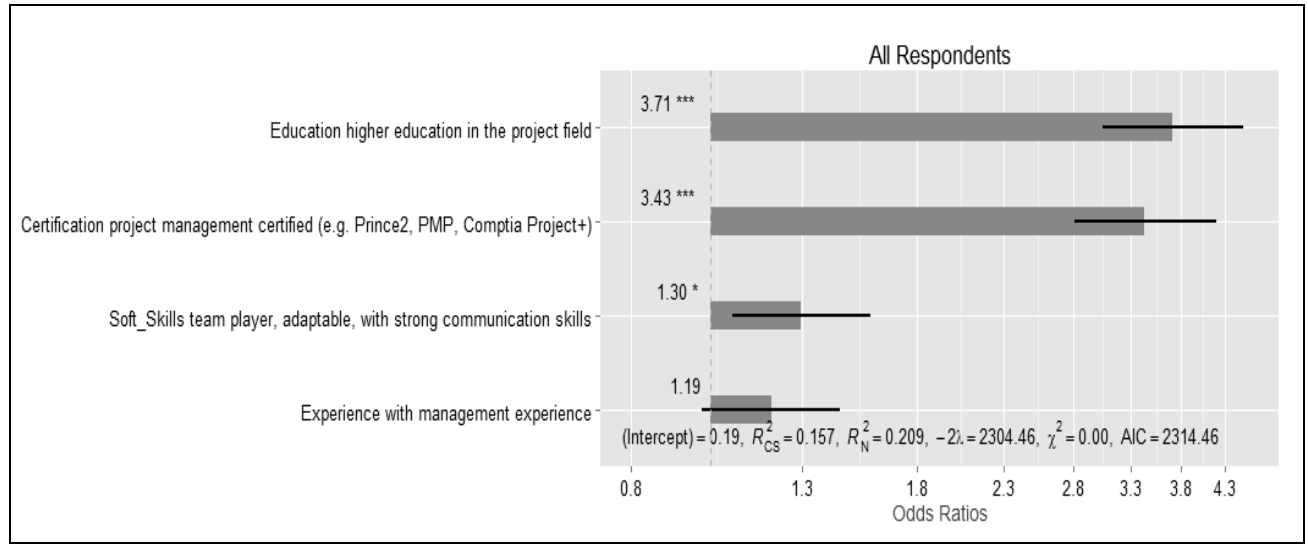

Figure no. 2: Odds ratios of the four factors

In the third phase of the research, an in-depth analysis of the responses was made to complement previous studies on the profile of a good project manager. Thus, we analysed which was the most frequently selected project manager profile. The analysis allowed us to create a hierarchy of preferences for the profiles as presented in (table no. 5). For example, profile 5 (with management experience, PM certification, higher education in the project field and with teaching, training and mentoring skills) is the most preferred profile, and it is followed, in the second position, by the profile 1 with the main differences related to 'management experience' and 'soft skills'.

Candidates with management experience and mentoring skills are preferred to candidates with technical experience and team players. Moreover, the conjoint analysis (CA) can be used as an instrument for scenarios evaluation and simulations. Using CA on collected data enables to explore alternative projects managers' profiles. Computer simulations can be run to identify the point at which the candidates' profiles are more appreciated by key project stakeholders. For specific projects, the key stakeholders (the sponsor or owner of the project for example) might appreciate soft skills more than certifications, and technical education more than management education. The preferences of key stakeholders can be assessed by using conjoint simulations and ease the recruitment and selection process for best-suited candidates for the project manager role.

Table no. 5: Mean values for profiles used in pairs to assess the respondent preference

\begin{tabular}{|c|l|l|l|l|c|}
\hline Profile & Experience & Certifications & Education & Soft Skills & $\begin{array}{l}\text { The mean values } \\
\text { corresponding to } \\
\text { the profiles } \\
\text { presented in pairs }\end{array}$ \\
\hline 1 & $\begin{array}{l}\text { technical } \\
\text { experience }\end{array}$ & $\begin{array}{l}\text { project } \\
\text { management } \\
\text { certified }\end{array}$ & $\begin{array}{l}\text { education in } \\
\text { the project } \\
\text { field }\end{array}$ & $\begin{array}{l}\text { team player, } \\
\text { adaptable, strong } \\
\text { communication } \\
\text { skills }\end{array}$ & 6.15 \\
\hline
\end{tabular}




\begin{tabular}{|c|c|c|c|c|c|}
\hline Profile & Experience & Certifications & Education & Soft Skills & $\begin{array}{l}\text { The mean values } \\
\text { corresponding to } \\
\text { the profiles } \\
\text { presented in pairs }\end{array}$ \\
\hline 2 & $\begin{array}{l}\text { technical } \\
\text { experience }\end{array}$ & & $\begin{array}{l}\text { education in } \\
\text { the project } \\
\text { field }\end{array}$ & $\begin{array}{l}\text { team player, } \\
\text { adaptable, strong } \\
\text { communication } \\
\text { skills }\end{array}$ & 5.87 \\
\hline 3 & $\begin{array}{l}\text { management } \\
\text { experience }\end{array}$ & $\begin{array}{l}\text { project } \\
\text { management } \\
\text { certified }\end{array}$ & & $\begin{array}{l}\text { team player, } \\
\text { adaptable, strong } \\
\text { communication } \\
\text { skills } \\
\end{array}$ & 5.18 \\
\hline 4 & $\begin{array}{l}\text { management } \\
\text { experience }\end{array}$ & & & $\begin{array}{l}\text { team player, } \\
\text { adaptable, strong } \\
\text { communication } \\
\text { skills } \\
\end{array}$ & 3.39 \\
\hline 5 & $\begin{array}{l}\text { management } \\
\text { experience }\end{array}$ & \begin{tabular}{|l} 
project \\
management \\
certified
\end{tabular} & $\begin{array}{l}\text { education in } \\
\text { the project } \\
\text { field }\end{array}$ & $\begin{array}{l}\text { teaching, training } \\
\text { and mentoring } \\
\text { skills }\end{array}$ & 7.36 \\
\hline 6 & $\begin{array}{l}\text { management } \\
\text { experience }\end{array}$ & & $\begin{array}{l}\text { education in } \\
\text { the project } \\
\text { field }\end{array}$ & $\begin{array}{l}\text { teaching, training } \\
\text { and mentoring } \\
\text { skills }\end{array}$ & 4.52 \\
\hline 7 & $\begin{array}{l}\text { technical } \\
\text { experience }\end{array}$ & $\begin{array}{l}\text { project } \\
\text { management } \\
\text { certified }\end{array}$ & & $\begin{array}{l}\text { teaching, training } \\
\text { and mentoring } \\
\text { skills }\end{array}$ & 4.68 \\
\hline 8 & $\begin{array}{l}\text { technical } \\
\text { experience }\end{array}$ & & & $\begin{array}{l}\text { teaching, training } \\
\text { and mentoring } \\
\text { skills }\end{array}$ & 2.84 \\
\hline
\end{tabular}

\section{Conclusions}

The project manager represents the interests of the project in relationship to the permanent organization and key stakeholders, coordinates, motivates and leads the project team towards the desired results. The role of the project manager is complex and has the highest influence on achieving the objectives and meeting the success criteria. Although distinct types of projects might require different profiles of project managers, some skills and competencies are preferred depending on those making the hiring decision. The empirical research shows that persons involved in project manager's selection perceive differently the value of professional competencies and skills of the project manager, based on their professional role: organisations' managers vs. HR specialists. By using conjoint analysis, we found that the most influential factors in hiring a project manager are education in the project field (IT, engineering and construction etc.), followed by project management certifications (PMP, Prince2, Comptia Project+ etc.). Moreover, organisations' managers appreciate differently than HR specialists what is important when hiring a project manager. Human resources specialists are better prepared theoretically to determine the best suited profile according to the tasks of the project manager, while organisations' managers know better the context of the project. This different perception is normal and can benefit the 
selection process if there is a collaboration between the organisations' managers and the specialists in human resources. Also, project management certifications are valued more by European respondents than by respondents from other continents. While, certifications are more appreciated than soft skills like mentoring or communication.

Although the number of analysed cases is relevant to satisfy statistical assumptions for the models and tests, it is not enough to infer conclusions for a large population, since due to resources limits, we have not imposed the correspondent sampling constraints. The uniqueness of projects also limits the generalisation possibility of the results. However, the results enhance the existing literature on the topic by analysing and presenting the perceptions of 119 persons involved in project managers' selection regarding the preferred profile of the candidate. As a future research, in-depth analysis can be conducted to analyse the relationship between the preferred skills and competencies of a project manager and project success.

\section{References}

Ahsan, K., Ho, M. and Khan, S., 2013. Recruiting Project Managers: A Comparative Analysis of Competencies and Recruitment Signals from Job Advertisements. Project Management Journal, 44(5), pp.36-54. doi: 10.1002/pmj.21366.

Bauer, B.J., Richardson, T.M. and Marion, J.W., 2014. Project Manager Management Competency vs. Technical Competency. Which is more important to overall project management success? International Journal of Engineering Research and Applications, 4(4), pp 269-273.

Bredillet, C., Tywoniak, S. and Dwivedula, R., 2015. What is a good project manager? An Aristotelian perspective. International Journal of Project Management, 33(2), pp.254-266. doi:10.1016/j.ijproman.2014.04.001.

Bredin, K. and Söderlund, J., 2013. Project managers and career models: An exploratory comparative study. International Journal of Project Management, 31(6), pp.889-902. doi:10.1016/j.ijproman.2012.11.010.

Chen, M.T., 1997. The modern project manager. Cost Engineering, 39(3), pp.27-30.

Crawford, L., 2005. Senior management perceptions of project management competence. International Journal of Project Management, 23(1), pp.7-16. doi:10.1016/ j.ijproman.2004.06.005.

Fisher, E., 2011. What practitioners consider to be the skills and behaviours of an effective people project manager. International Journal of Project Management, 29(8), pp.9941002. doi:10.1016/j.ijproman.2010.09.002.

Forsberg, K., Mooz, H. and Cotterman, H., 2005. Visualizing Project Management: Models and Frameworks for Mastering Complex Systems. 3rd ed. Hoboken New Jersey: Wiley.

Gareis, R., 2005. Happy Projects. Vienna: Manz Verlag.

Hölzle, K., 2010. Designing and implementing a career path for project managers. International Journal of Project Management, 28(2), pp.779-786. doi:10.1016/ j.ijproman.2010.05.004.

IPMA, 2015. Moving PM Competence Forward. [online] Available at: <http://ipma.ch/certification/> [Accessed 20 May 2018]. 
Joseph, N. and Marnewick, C., 2018. Investing in project management certification: Do organisations get their money's worth?. Information Technology and Management, 19, pp.51-74. doi.org/10.1007/s10799-017-0275-y.

Kar, N. and Mitra, S., 2015. Recruiting a Project Manager: A Hiring Manager's Perspective. International Journal of Information Technology Project Management, 6(1), pp.54-65. doi: 10.4018/ijitpm.2015010103.

Karlsen, J.T. and Gottschalk, P., 2006. Project Manager Roles in IT Outsourcing. Engineering Management Journal, 18(1), pp. 3-9. doi: 10.1080/ 10429247.2006.11431678.

Ma, R. and Allen, D, 2009. Recruiting across cultures: A value-based model of recruitment. Human Resource Management Review, 19(4), pp.334-346. doi:10.1016/ j.hrmr.2009.03.001.

Mediouni, A., Zufferey, Z., Subramanian, N. and Cheikhrouhou, N., 2018. Fit between humanitarian professionals and project requirements: hybrid group decision procedure to reduce uncertainty in decision-making. Annals of Operations Research, 283, pp.471496doi.org/10.1007/s10479-018-2782-6.

Mir, F.A. and Pinnington, A.H., 2014. Exploring the value of project management: Linking Project Management Performance and Project Success. International Journal of Project Management, 32(2), pp.202-217. doi:10.1016/j.ijproman.2013.05.012.

Morris, P.W.G., Crawford, L., Hodgson, D., Shepherd, M.M. and Thomas, J., 2006. Exploring the role of formal bodies of knowledge in defining a profession - The case of project management. International Journal of Project Management, 24(8), pp.710721. doi:10.1016/j.ijproman.2006.09.012.

Muller, R. and Turner, R., 2010. Leadership competency profiles of successful project managers. International Journal of Project Management, 28(5), pp.437-448. doi:10.1016/j.ijproman.2009.09.003.

Obradovica, V., Jovanovicb, P., Petrovica, D., Mihica, M. and Mitrovic, Z., 2013. Project Managers' Emotional Intelligence - A Ticket to Success. Procedia - Social and Behavioral Sciences, 74, pp. 274-284. doi:10.1016/j.sbspro.2013.03.034.

Office of Government Commerce, 2009. An introduction to PRINCE2: Managing and Directing Successful Projects. London: The Stationery Office.

Project Management Institute, 2007. Project Manager Competency Development (PMCD) Framework. 2nd ed. Newtown Square, PA: Project Management Institute.

Project Management Institute, 2013a. Project Management between 2010-2020. Project Management Talent Gap Report. [online] Available at: <http://www.pmi.org/Learning/pulse/ /media/PDF/Business-

Solutions/PMIProjectManagementSkillsGapReport.ashx> [Accessed 22 May 2017].

Project Management Institute, 2013b. Pulse of the Profession In-Depth Report: The Impact of PMOs on Strategy Implementation. [online] Available at:

$<$ http://www.pmi.org/ /media/PDF/Publications/PMI-Pulse-Impact-of-PMOs-onStrategy-Implementation.ashx> [Accessed 20 March 2017].

Project Management Institute, 2015. Certifications. [online] Available at: <http://www.pmi.org/Certification.aspx> [Accessed 22 May 2017]. 
Pollack, J. and Algeo, C., 2016. Project managers' and change managers' contribution to success. International Journal of Managing Projects in Business, 9(2), pp.451-465. doi: 10.1108/IJMPB-09-2015-0085.

Ramazani, J. and Jergeas, G., 2015. Project managers and the journey from good to great: The benefits of investment in project management training and education. International Journal of Project Management, 33(1), pp. 41-52. doi:10.1016/ j.ijproman.2014.03.012.

Salas Velasco, M., 2012. More than just good grades: candidates' perceptions about the skills and attributes employers seek in new graduates. Journal of Business Economics and Management, 13(3), pp.499-517. doi: 10.3846/16111699.2011.620150.

Segalla, M., Sauquet, A. and Turati, C., 2001. Symbolic vs. Functional Recruitment: Cultural Influences on Employee Recruitment Policy. European Management Journal, 19(1), pp.32-43. doi:10.1016/S0263-2373(00)00069-4.

Serrador, P., Pinto, J.K., 2015. Does Agile work? - A quantitative analysis of agile project success. Int. J. Proj. Manag, 33(5), pp.1040-1051. doi.org/10.1016/ j.ijproman.2015.01.006.

Shenhar, A.J., Dvir, D., Levy, O. and Maltz, A.C., 2001. Project Success: A Multidimensional Strategic Concept. Long Range Planning, 34(6), pp.699-725. doi:10.1016/S0024-6301(01)00097-8.

Sommerville, J., Craig, N. and Hendry, J., 2010. The role of the project manager: all things to all people?. Structural Survey, 28(2), pp.132-141. doi: 10.1108/ 02630801011044235 .

Taylor, S., 2006. Acquaintance, meritocracy and critical realism: Researching recruitment and selection processes in smaller and growth organizations. Human Resource Management Review, 16(4), pp.478-489. doi:10.1016/j.hrmr.2006.08.005.

Westerveld, E., 2003. The Project Excellence Model: linking success criteria and critical success factors. International Journal of Project Management, 21(6), pp.411-418. doi:10.1016/S0263-7863(02)00112-6.

Zhang, F., Zuo, J. and Zillante, G., 2013. Identification and evaluation of the key social competencies for Chinese construction project managers. International Journal of Project Management, 31(5), pp.748-759. doi:10.1016/j.ijproman.2012.10.011. 